\title{
Seasonal changes in reproductive cycle of female fresh water prawn, Macrobrachium dayanum (Henderson) from river Gomti, Lucknow (India)
}

\section{Rashmi Tripathi}

Department of Bioscience and Biotechnology, Banasthali Vidyapith, Banasthali- 304022, (Rajasthan), India

Sanjive Shukla

Department of Zoology, BSNVPG College, Lucknow (Uttar Pradesh), India

U. D Sharma*

Retd Professor, Department of Zoology, University of Lucknow, Lucknow (Uttar Pradesh), India

*Corresponding author. E-mail: dr.u.d.sharma@gmail.com

\begin{abstract}
The present study was conducted on the experimental animals, Macrobrachium dayanum (Henderson) (Crustacea: Decapoda) to analyze the seasonal changes in reproductive cycle of female, found at different locations in river Gomti $\left(26^{\circ} 55^{\prime} ; 80^{\circ} 59^{\prime} \mathrm{E}\right)$, in and around Lucknow (U.P. India). The reproductive activities were found in cyclic manner in M.dayanum, which breeds continuously throughout the year but with two distinct peaks one major in the month of May-July and one minor in the month of January - Feburary. Five stages of Oogenesis i.e. proliferative, meiotic, previtellogenic, vitellogenic and resorbtion or atretic oocyte phase have been recorded in $M$. dayanum. Mature ova were noticed in two peaks i.e. major in month of July - August and September and minor in months of February and March. Histoarchitecture of hepatopancreas showed seasonal changes in accordance with the gonadal development. The reproductive cycle of M.dayanum is reported for the first time and very little work is known on the seasonal changes with respect to reproduction and its correlation with hepatopancreas.
\end{abstract}

Keywords: Freshwater prawn, Hepatopancreas, M. dayanum, Ovary, Seasonal, Reproductive cycle

\section{INTRODUCTION}

The small fresh water prawn, Macrobrachium. dayanum (Henderson) belongs to family palaemonidae of Decapod - Crustaceans are of great commercial significance. This species occupy a significant place in U.P particularly in Lucknow, where it is easily available and consumed as food. This species is even included in the list of culturable prawns of the world (Holthuis, 1980; Jayachandran, 1998; Jayachandran, 2001) and contributes to the livelihood of the downtrodden by way of food supply, employment and income generation.

The prawns contain a rich amount of proteins, free amino acids, and omega 3 fatty acids vitamin A and $D$ etc, due to less fat in prawns it is advised to diabetic people. The nutritional constituent in prawns is considered to be highly beneficial to human health and has a protective role against many diseases. (Proudfit and Robinson, 1955; Martin, 1996; Singh, 1977; Khan et al., 1994; Sofia and Vassilia, 2012). Crustaceans constitute the group with free amino acids as the nitrogenous

\section{Article Info}

DOI:10.31018/jans.v11i1.1966 Received: December 20,2018 Revised: February 14, 2019 Accepted: February 22, 2019

\section{How to Cite}

Tripathi, R. et al. (2019). Seasonal changes in reproductive cycle of female fresh water prawn, Macrobrachium dayanum (Henderson) from river Gomti, Lucknow (India). Journal of Applied and Natural Science, 11(1): 149-154 compounds in their muscles. These free amino acids results in the unique flavor and taste to crustaceans (Turan et al., 2011; Karnjanapratum et al., 2013; Grienke et al., 2014; Bogard et al., 2015; Vazhiyil and Kumarapanicker, 2017).

Prawns being very sensitive to pollutants are considered as good bio-indicators. With the increasing demand of fresh water prawns, it becomes important to study their reproductive biology (Patwardhan, 1937; Jayachandran and Joseph, 1986; Elorza and Dupre, 2000; Jayachandran, 2001; Jayawardane et al., 2002; Peter et al., 2006 and Webb 2011). Aquaculture production decreased because stock from the wild varies in quality and quantity of supply. The study of reproductive system becomes important to successfully culture and increase the production of prawns at industrial level (Olele et al., 2012).Considering the above facts, present work has been taken into account to study reproductive cycle of fresh water prawn, M. dayanum.

\section{MATERIALS AND METHODS}

The fresh water prawn, M. dayanum (Henderson) 
Tripathi, R. et al. / J. Appl. \& Nat. Sci. 11(1): 149-154 (2019)

(Crustacea - Decapoda), a bottom dweller, commonly known as "Jhinga" in countryside, were collected from river Gomti at different localities in and around Lucknow (U.P.) India, with the help of local fisherman and brought to the laboratory $(\mathrm{N}$ $26^{\circ} 5^{\prime} 59^{2} \mathrm{E}-80^{\circ} 56^{\prime} 17^{2}$ ). Prawns were kept in $20 \mathrm{lt}$ glass aquaria and separating the animals into two categories: females and berried females. Adult intermolt staged female animals were used for experimental purpose as per requirement (Fig 1). The animals were maintained in water having following physio-chemical characteristics (Sharma and Shukla, 1990; APHA, 2017) (pH-7.66 \pm 0.27 ; Temperature: $27.66 \pm 0.66{ }^{\circ} \mathrm{C}$; Partial Alkalinity: $18.75 \pm 3.75 \mathrm{mg} / \mathrm{l}$; Total Alkalinity: $425 \pm 11.36$ $\mathrm{mg} / \mathrm{l}$; Total Hardness : $268 \pm 2.67 \mathrm{mg} / \mathrm{l}$ Dissolved Oxygen : $6.6 \pm 0.74 \mathrm{mg} / \mathrm{l})$. Animals before being used for experimental purpose were acclimated to laboratory conditions for at least 5-7 days and were fed with Tokyo, an artificial food supplement available in the market. The female animals were found to have an average Length: $3.12 \pm 0.14 \mathrm{~cm}$ and average weight: $0.52 \pm 0.03$ gm.

The ovary and hepatopancreas were selected as target tissue for the seasonal study of the reproductive cycle in prawn on freshly collected animals in every $3^{\text {rd }}$ week of the month of the year. The female animals were dissected in Crustacean Ringer's Solution (Brown and Creedy, 1970) for each month, the tissues were fixed in alcoholic Bouin's for $24 \mathrm{~h}$, the tissue were then dehydrated and blocks prepared using paraffin wax $\left(60-62^{\circ} \mathrm{C}\right)$, the thin sections of $6-8 \mu$ were cut using a rotatory microtome and stained with Harris's haematoxyline and eosin and studied under Olympus Trinocular Microscope to observe the histological changes and photographed (Fig: 2)

\section{RESULTS AND DISCUSSION}

Seasonal changes in ovaries: The gonads of M.dayanum were found in several stages on the basis of external morphology and colour such as Stage I (Immature), Stage II (Early Maturing), Stage III (Late maturing), Stage IV (Maturing) and Stage V(Spent or recovering). This cytological classification of the female gonads into five phases was based on the size of the ova. Stage I or the proliferative phase when the ovary is undeveloped, thin, translucent unpigmented and confined in the abdominal region. The ovary at this stage possesses large number of dividing gonial and oogonial cells at the germinal zone of the ovary and is basophilic with small amount of ooplasm and chromatin material visible in the nucleus. The ovum at this stage is small spherical having a clear cytoplasm and large nucleus. Stage II or meiotic phase the size of the ovary increase and becomes opaque and tubular getting divided into lobes. The oogonia are larger than in the prolifera- tive phase and nucleus occupies almost all the cellular volume with uniform chromosomes surrounded by follicular cells. Stage III or the previtellogenic phase the ovary becomes green, thickened, swollen and ova were visible in which the oocytes starts dividing rapidly and have a regular shape. Nucleolus begins to differentiate and start migrating towards the periphery of the nucleus and oocytes at this stage migrate towards the periphery of the ovary forming ovarian follicle. The ovum at this stage becomes large due to the accumulation of yolk and thus becomes opaque. Stage IV the vitellogenic or mature ovum was visible through the exoskeleton. Ova are green thick swollen and rounded at the anterior ends located in the periphery of the ovary having acidophilic cortical granules and also having lipid droplets with nucleus in the centre. Stage $V$ the resorbing or atretic oocytes ovarian lobes becomes flaccid soft and thin not functional in nature and decreases in size. Nucleus is not visible and they slowly get destructed (Fig 3: 1-12)

Five developmental stages in Oogenesis Proliferative, Meiotic, previtellogenic, vitellogenic and resorbing or atretic oocyte phases have been recorded in M.dayanum. Similar sequence of developmental stages of ovum has also been reported from various crustaceans (Nagabhushanam and Joshi, 1985; Demestre and Fortuno, 1992; Kao et al., 1999; Palmer et al., 1995; Nandkumar, 2001; Rafael et al., 2010 and Alves, 2019). Almost simi-

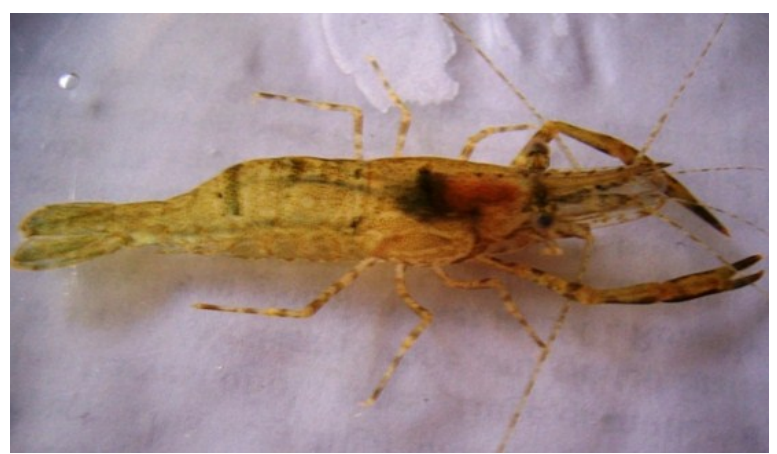

Fig.1. Photograph shows the female M.dayanum.

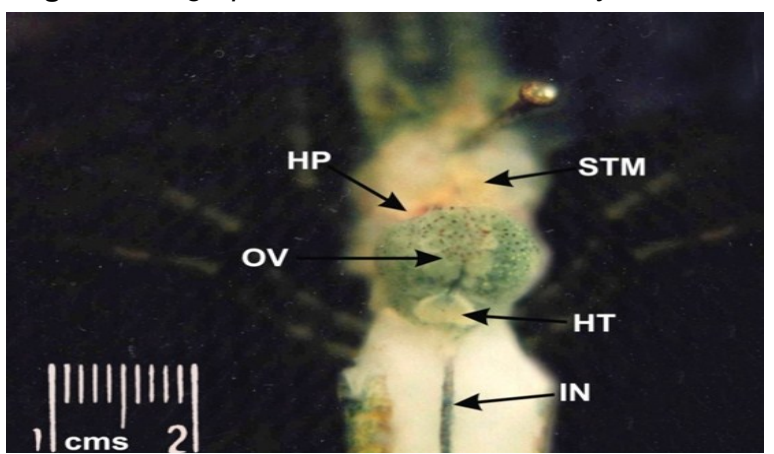

Fig.2. Photograph of dissection of female M. dayanum, showing the position of the different parts of reproductive system (HP hepatopancreas; HT heart; OV ovary; OVD oviduct; STM stomach; IN Intestine). 
Tripathi, R. et al. / J. Appl. \& Nat. Sci. 11(1): 149-154 (2019)
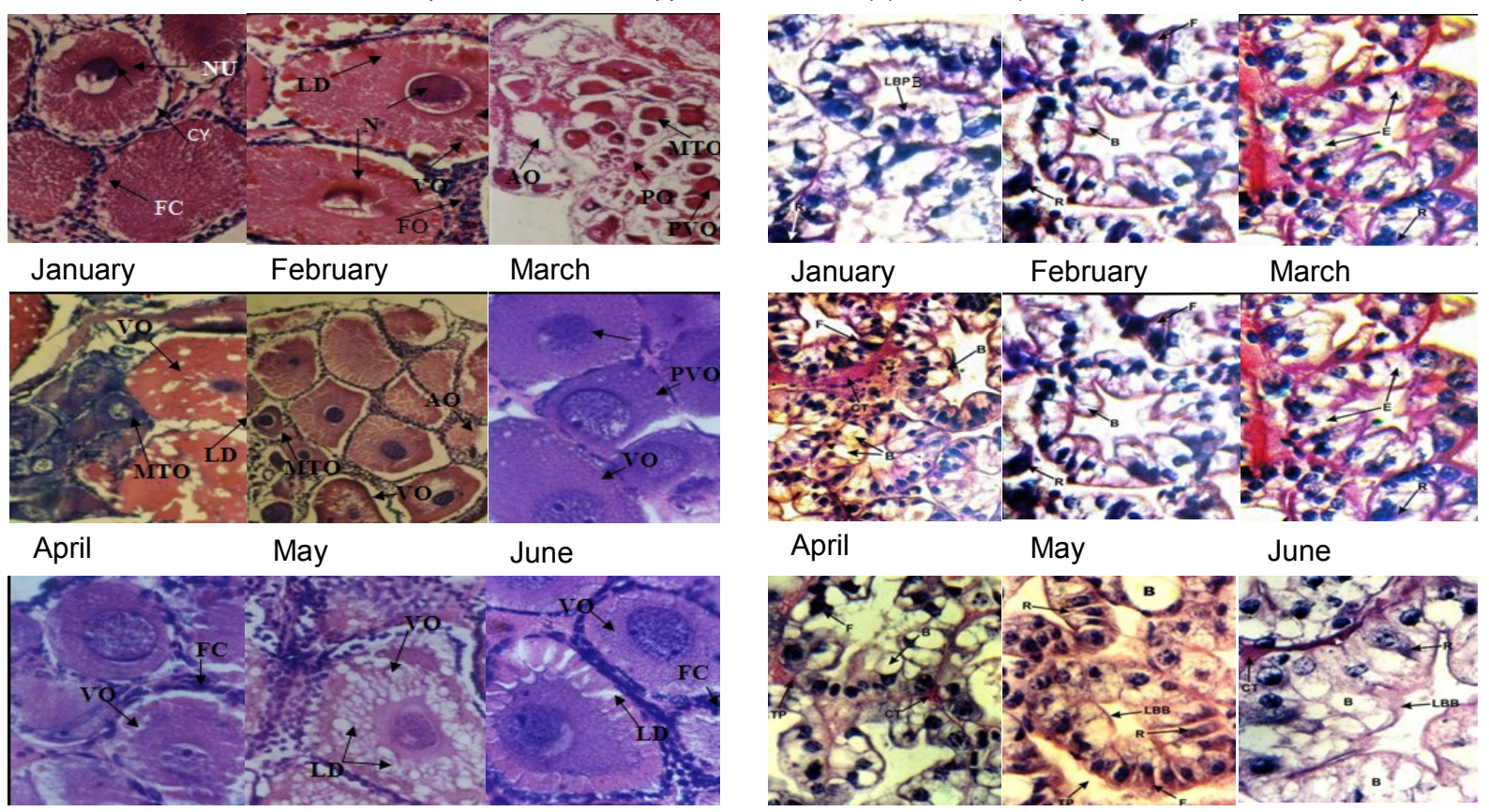

April

May

June

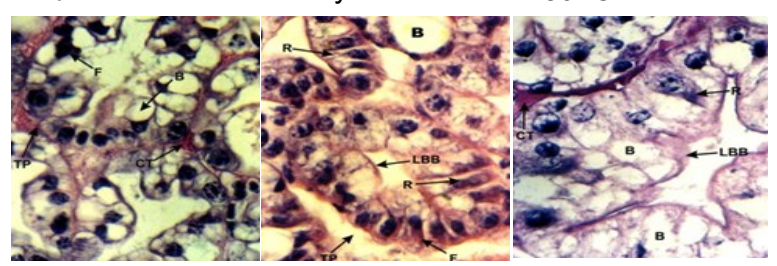

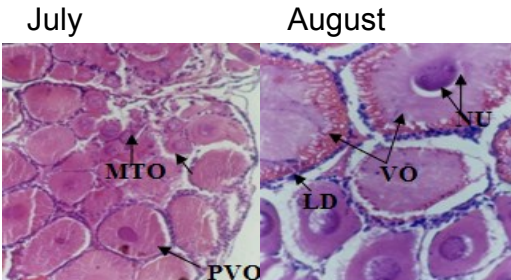

October

November
September

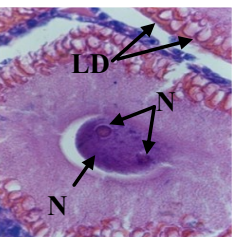

December

Fig. 3 (Jan - Dec). Photomicrographs of T.S. of Ovary of M.dayanum depicting the seasonal changes in the ovary (scale bars $=50 \mu m$ ) (CY: Cytoplasmic yolk; Nu: Nucleolus; N: Nucleus; PO: Proliferative Ovum; AO: Atretic Oocytes; MTO: Meiotic ovum; PVO: Pre-Vitellogenic ovary; VO: Vitellogenic ovary; LD: Lipid droplets; FC: Follicular cells).

lar structure and sequence of developmental stages of oogenesis consisting oogonium, Primary oocyte, Early vitellogenic, vitellogenic, Late vitellogenic phase have been reported in Ganga water prawn M. birmanicum chopri (Singh et al., 1988) in $M$. rosenbergii (Chang and Shih, 1995) and in atyid prawn, Caridina rajadhari (Victor and Sarojini, 1985).

The oval non germinative accessory follicular cells were noticed in close association with the early vitellogenic stage of oocyte in M.dayanum in present study. Similar follicular cells have been reported by Singh et al., (1988) in M.birmanicum chopri; Victor and Sarojini, (1985) in Caridina rajadhari ; Nagabhushanam and Joshi, (1985) in Paranenaeopsis stylifera ; King, (1948) in Penaeus setiferus ; Kao et al., (1999) in Aristaeomorpha foliacea and Elorza and Dupre, (2000) in spiny rock lobster Jasus frontalis. These cells are believed to play very important role in vitellogenesis

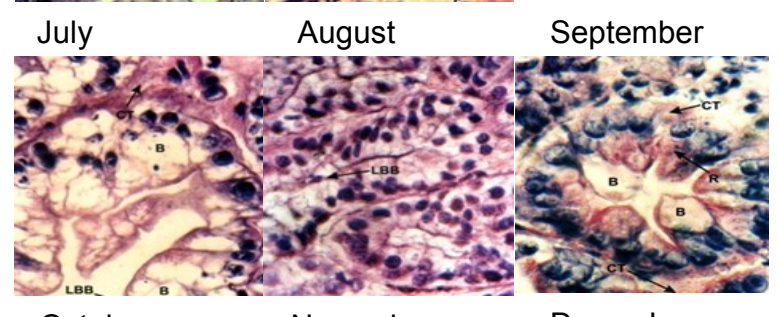

October

November

December

Fig. 4 (Jan - Dec). Photomicrographs of T.S. of Hepatopancreas in female of M.dayanum depicting the seasonal changes in the hepatopancreas (scale bars $=50 \mu m$ ) (CT: Connective Tissue; LBB: Luminous Brush Border; TP: Tunica Propria; B: BCells; F: F-cell).

as some amount of synthetic activity has also been assigned in them. Nutritive phagocytes appear to be modified follicle cells and found phagocytising the older oocytes and thus causing their degeneration in P.stylifera (Nagabhushanam and Joshi, 1985). Similar kind of functional role also appears true in case of M.dayanum as evident from histological preparations. The role of nutritive phagocytes, after they bring about degeneration is not known. The possibility that these nutritive phagocytes may give up their contents to a fresh lot of the oocytes and /or their contents released into the haemolymph cannot be ruled out.

Changes in hepatopancreas: Hepatopancreas of $M$. dayanum showed seasonal changes in its histological architecture in accordance with the gonads. The cell size and activity of hepatopancreatic tubular cells was found highest in month of January - Feburary in females. While the cell size and activity of particularly $B$ and $R$ cells was found 
highly reduced in month of Feburary - March and July - September, while the cell size was found increased in month of May - June and December - January. The B- cells and R-cells were found loaded with vacuoles and lipid droplets. (Fig 4:1-12).

As it is well known that decapod hepatopancreas serves to absorb nutrients as well as stores reserve materials like glycogen, lipid, calcium etc. The organic reserves from hepatopancreas are known to be cyclically mobilized to the gonads during reproduction as well as to epidermis during moulting (Adiyodi and Adiyodi, 1970). The cell size and dominance of cell type $(E, B, F, R)$ depends on the activity of hepatopancreas in accordance with the gonadal cycle (Franceschini-Vicentini, 2009 and Silva, 2018). Almost similar findings, as observed in present study have been reported in atyid prawn $C$. weberi (Nagabhushanam et al., 1984), in C. rajadhari (Victor, 1987) and in $M$. lanchesteri (Narsimha et al., 1981).

The mobilization of organic reserves like protein from hepatopancreas to gonads have been studied in palaemonidae and penaeid prawns (Nagabhushanam, 1989; Kulkarni et al., 1979; Mohamed and Diwan, 1992). Similarly, lipid is also known to store in hepatopancreas of prawns and crabs (Kulkarni and Nagabhushanam, 1979) and be mobilized from hepatopancreas to ovary (Joshi and Diwan, 1996; Kanazawa and Teshima, 1971). The size and shape of hepatopancreatic epithelial cells can be established as indexed in relation to gonadal maturation as also reported by (Rao et al., 1981).

The antagonistic relation between ovary and hepatopancreas lipid contents has been observed by various workers like Kumar, (1980) in P. hydrodromus; Varadarajan and Subramoniam, (1982) in C. cilibanaricus and Mohammed and Diwan, 1992 in $P$. indicus may also be true for antagonistic relation between cell size of hepatopancreas and ovarian development observed in present study (Kale et al., 2011 and Revathi et al., 2012).

The carbohydrate content of hepatopancreas have also been reported to fluctuate according to the maturation stage of gonads particularly ovary as observed in P.hydrodromus (Adiyodi and Adiyodi, 1970) in P. hardwickii (Kulkarni and Nagabhushanam, 1979) and in Caridina weberi (Nagabhushanam and Joshi, 1985 and Mohammed and Diwan, 1992) who observed active mobilization of the carbohydrate from hepatopancreas to the ovary during metabolism. The mobilization of organic reserves mainly affect the activity of $R$ and $B$ cells of the hepatopancreas (Gibson and Baker, 1979 and Revathi et al.,(2012) which may be the reason for change in histological architecture of hepatopancreas according to gonadal maturation as observed in present study.

The increased activity as well as number of wan- dering cells in the hepatopancreas also indicates the transport of organic reserves particularly vitellogens from hepatopancreas to ovary (Wolin et al., 1973) as it is well known that wandering cells are involved in transport of vitellogens during ovarian maturation in various crustaceans like Metapenaeus bennewtae (Dall, 1967); C. meanas and Libinia emerginata (Paulus and Lucifer, 1987); Palaemonetes zariquiegi (Sagarista and Durfort, 1990) ; and Ocypode ceraptothalmus (Remlath and Adiyodi,1996). This may be the reason for the changes in cell activity and structure in hepatopancreas. The Increased and decreased activity of Wandering cell also supports the present conclusion as wandering cells as also known to involve in transport of Vitellogens. The measurement of hepatopancreas activity can be done by measuring height of the hepatopancreas epithelial cells as also reported by Rao et al., 1981. Present observations are nearer to the reportings of Biswas and Qureshi, 1994 the minor variations observed in present study of M.dayanum may be due to variation in geographical and climatic conditions.

\section{Conclusion}

In the present study the reproductive activities were found in cyclic manner in M.dayanum and it breeds continuously with two peaks, major in the month of May-July and minor in the month of January- Feburary. The ovary shows five stages and active mobilization of carbohydrate and lipids from the hepatopancreas to the ovary, effecting the activity of $R$ and $B$ cells of the hepatopancreas responsible for the histological variation. The increased activity and the number of wandering cells are involved in the transportation of vitellogens during ovarian maturation. The seasonal changes in its histological architecture of the hepatopancreas were in accordance with gonadal changes and found to be prominent in females. The changes in correlation shows that the hepatopancreas absorb and store reserve food materials like glycogen, lipid, and calcium and are mobilized to the gonads during reproduction. The cell size and dominance of the cell type $E, B, F$ and $R$ depends on the activity of hepatopancreas in accordance with the gonadal cycle. This study thus establishes the antagonistic relationship between the cell size of hepatopancreas and ovarian development.

\section{ACKNOWLEDGEMENTS}

The author wishes to thank the Head, Department of Zoology, University of Lucknow, Lucknow for providing, the necessary facilities to carry out the research work.

\section{REFERENCES}

1. Adiyodi, R.G., and Subramanium, T. (1983). Arthop- 
oda-Crustaces. In reproductive biology of invertebrates, Oogenesis and moultig. Physiol. Zool. 43 (1):71-77

2. Adiyodi, K.G. and Adiyodi, A.G. (1970). Endocrine control of reproduction in decapod crustacea. Biol.Rev. 45:121-165

3. Agarwal, S.K. (1996). Ovarian morphology, histology, histochemistry and seasonal Cyclicity, In fish reproduction. APH Publishing corporation, New Delhi.

4. Alves, D.F.R., Laura, S. Lopez-Greco., Barros-Alves, SdP., Hirose, G.L. (2019). Sexual system, reproductive cycle and embryonic development of the redstriped shrimp, Lysmata vittata, an invader in the western Atlantic Ocean. PLoS ONE, 14(1):e0210723

5. Anil kumar, G. (1980). Reproductive physiology of female crustaceans. Ph.D Thesis, Calicut University, Kerala.India

6. APHA. (2017).Standard Methods for the examination of water and waste waters. $23^{\text {rd }} \mathrm{Edn}$. APHA, AWWA \& WPCF Washington.

7. Biswas, R. and Qureshi, T. A. (1994). Annual reproductive cycle of the fresh water prawn, Macrobrachium dayanum (Henderson, 1893). Naturalia. 19:131147.

8. Bogard, J.R., Thilsted, S.H., Marks, G.C., Wahab, M.A., Hossain, M.A.R., Jakobsen, J., Stangoulis, J. (2015). Nutrient composition of important fish species in Bangladesh and potential contribution to recommended nutrient intakes. J Food Comp. Anal. 42:120 $-33$

9. Brown, G.D. and Creedy, J. (1970). Experimental biology manual. Heinemann Educational Books Ltd., London.

10.Chang, C.F. and Shih, T.W. (1995). Reproductive cycle of the ovarian development and vitellogenin profiles in the fresh water prawns, Machrobrachium rosenbergii. Invert.Reprod.Develop.21: 11-20.

11.Dall, W. (1967).The fuctional anatomy of the digestive tract of a shrimp, Metapenaeus bennettae, Recek and Dall. (Crustacea: Decapoda: Penaeidae). Aust.J.Zool.15: 699-714.

12.Dasgupta, M.(1988): Length-weight relationship and condition of the copper mahseer, Acrossochilus haxagunolepis (MaClelland). Matsaya14: 79-91.

13.Demestre, M. and Fortuno, J.M. (1992). Reproduction of the deep -water shrimp Aristeus antennatus (Decapoda-Dendrobranchiata). Mar. Ecol. 84:41-51

14.Elorza, A. and Dupre, E. (2000). Ovary architecture of the Juan fernandez spiny rock lobster, Jasus frontalis. Invest. Mar. 28:175-194.

15.France schini-vicentini, I. B., Ribeiro, K., Papa, L. P., Marques, Junior. J., Vicentini, C. A. and Valenti, P. M. C. M. (2009).Histoarchitectural features of the hepatopancreas of the amazon river prawn Macrobrachium amazonicum. Int. J. Morphol, 27(1):121128.

16.Gibson, R. and Barker, P.I. (1979). The decapod hepatopancreas. Oceanogr. Mar. Biol. Ann. Rev.17: 285-346.

17.Grienke, U., Silke, J. and Tasdemir, D. (2014). Bioactive compounds from marine mussels and their effects on human health. Food Chem. 142:48-60

18. Holthuis, L.B. (1980). Shrimp and prawns of the world: An annotated catalogue of species of interest of fisheries. FAO Fisheries synopsis. 125 (1): 1-272

19.Jayachandaran, K.V. (2001). Palaemonid prawns: Biodiversity, Taxonomy, Biology and Management.
Oxford \& I BH Publishing Co- Pvt. Ltd. New Delhi.

20.Jayachandran, K.V. (1998). Taxonomic status of Macrobrochium birmanicum and $M$. chopari (Tiwari) with a note on closely related species. Indian. J. Fisheries. 45(3): 345-349.

21.Jayachandran, K.V. and Joseph, N.I.(1986). Male reproductive system of the slender river prawn, Macrobrachium idella (Hilgendorf, 1898). Annals of Zoology XXIV (2): 78-87.

22.Jayawardane, P.A.A.T., Mclusky, D.S. and Tytler, P. (2002). Reproductive biology of Penaeus indicus (H.Milne Edwards, 1837) from the western coastal waters of Sri Lanka. Asian Fisheries Science 15 (2002): 315-328.

23.Joshi, V.P. and Diwan, A.D. (1996): Biochemical Changes in the tissue of female prawn Macrobrachium idella (hilgendorf, (1898) during differnrt breeding seasons. $J$ of Aquaculture in the Tropics. 11(3): 227 251

24.Kale, R. S., Shejule, K. B. and Sonawane, A. K. (2011). Hormone induced biochemical changes in the ovary and hepatopancreas in freshwater crabs, Barytelphusa cunicularis. The Bioscan,6(2): 199-201.

25. Kanazawa, A. and Teshima, S. (1971). In vivo conversion of cholesterol to steroid hormones in the spiny lobster Panulirus japonica. Bull.Jpn.Soc. Sci.Fish. 37: 891-903.

26.Kao, H.C., Chan T. and Yu, H.P. (1999). Ovary development of the deepwater shrimp Aristaeomorpha foliacea (Risso, 1826) (Crustacea: Decapoda: Aristeidae) from Taiwan. Zoological Studies 38(4):373-378.

27.Karnjanapratum, S., Benjakul, S., Kishimura, H. and Tsar, V.H. (2013). Chemical composition and nutritional value of Asian hard clam Meretrix lusoria from the coast of Andaman Sea. Food Chem. 141:413845

28.Khan, A.U., Sharma, V.P. and Azami, H.K. (1994). The medicinal use of entomological drugs used by tribal communities of Eastern Uttar Pradesh. J. Zoology. 14(1): $55-59$

29.King, J.E. (1948). A study of the reproductive organs of the common marine shrimp, Penaeus setiferus.Biol.Bull. 94: 244-262

30.Kulkarni, G.K. and Nagabhushanam, R \& Joshi, P. (1979). Effects pf progesterone on ovarian maturationin a marine penaeid prawn Parapenaeopsis hardwickii. Indian. J.Exp. Biol. 17: 986-987.

31.Martin, E.A. (1966). Nutrition in action. II ${ }^{\text {nd }}$ edition, Holt, Rinchort and Winston. New York.

32. Mohammed, K.S. and Diwan, A.D. (1992). Biochemical changes in different tissues during yolk synthesis in marine prawn, Penaeus indicus, H.Mine Edwards. Indian. J. Mar. Sci. 21:30-34

33.Nagabhushanam, R. and Joshi, P.K. (1985). Oogenesis in the penaeid prawn, Parapenaepsis stylifera. $\mathrm{J}$. Adv.Zool. 6(1): 18-22

34.Nagabhushanam, R. and Sarojini, R. (1989).Histopathological changes in the gills and hepatopancreas of the marine crab, Scylla serrata induced by an organophosphate, Dimecron. J. Adv. Zool. 8(1): 46-51

35.Nagabhushanam, R., Reddy, T.S.N and Sarojini, R. (1984). Biochemical nature of the ovary in relation to vitellogenesis in the freshwater Caridean prawn, Caridina weberi.Rev.Brasil.Biol.44: 295-298

36.Nandkumar, G. (2001). Reproductive biology of the speckled shrimp Metapenaeus monoceros 
Tripathi, R. et al. / J. Appl. \& Nat. Sci. 11(1): 149-154 (2019)

(Fabricius) Indian.J.Fish. 48(1):1-8

37.Narsimha, R., Katre, S. and Reddy, R.S. (1981). Moult - reproduction relationship in the fresh water prawn Macrobrachium lanchesteri (DeMan).Proc.Indian.Acad.Sci.90:39-52

38.Nkeonyeasua florence Olele., Prekeyi TawariFufeyin. and Josiah, Chidiebere, Okonkwo. (2012). Reproductive biology of freshwater prawn Macrobrachium vollenhovenii (herklot, 1857) caught in warri river Banats. J of Biotech. III (6)

39.Palmer, E.E., Sorensen, P.W. and Adelman, I.R. (1995). A histological study of seasonal ovarian development in fresh water drums in the red lakes, Minnesota. J.Fish.Biol. 47:199-210.

40.Patwardhan, S.S. (1937): The Indian zoological memoires, on Indian animal types (VI) Palaemon (the Indian River prawn). Lucknow publishing house Lucknow.100.

41.Paulus, J.E and Lucifer, H.(1987): Vitellogenocytes in the hepatopancreas of carcinus menas and libinia emarginata (decapoda, Brachyura).Int.J.Invert.reprod.Dev 11:29-44.

42.Peranandam, Revathi., Palanisamy, lyapparaj., Natesan, Munuswam., Muthukalingan, Krishnan. (2012). Vitellogenesis during the ovarian development in freshwater female prawn Macrobrachium rosenbergii(de man). Int. J. Aqu. Sci. 3(2):13-27

43.Peter B. Key, Edward F. Wirth \& Michael H. Fulton (2006) A Review of Grass Shrimp, Palaemonetes spp., as a bioindicator of anthropogenic impacts, Environmental Bioindicators, 1:2, 115-128,

44.Proudfit F.T. and Robinson, C.H. (1955). Nutrition and Diet therapy $11^{\text {th }}$ Edition Mcmillan Company New York.

45.Rafael A. Gregati., Vivian Fransozo., Laura S. Lopez -Greco. and Maria Lucia Negreiros-Fransozo. (2010). Reproductive cycle and ovarian development of the marine ornamental shrimp Stenopus hispidus in captivity. Aquaculture, 306(1-4):185-190

46.Rao, C.N., Shakuntala, K. and Reddy, S.R. (1981). Moult reproduction relationship in the fresh water prawn, Macrobrachium lanchesteri (deMan).Proc. Indian. Acad. Sci. (Anim.Sci.).90(1): 39-52

47.Remlath, P.K. and Adiyodi, R.G. (1996). Cells of the intertubular region of the hepatopancreas of the ghost crab, Ocypode ceratopthalamus J.Anim.Morphol.Physiol 42(1-2): 75-78

48.Sagarista,E. and Durfort, M. (1990). Ultrastructural study of haemocytes and phagocytes associated with haemolymphatic vessels in the hepatopancreas of
Palaemonetes zariquieyi.(Crustacea- Decapoda).J.Morphol.206:173-180

49.Sharma, U.D. and Shukla, S. (1990). Behaviour dysfunction of fresh water prawn, Macrobrachium lamarrei (Crustacea - Decapoda) following exposure to synthetic dertergent, linearalkyl Benzene Sulphonate. Biol. Mem. 16(12): 58-61

50.Silva, M.A.S., Almeida Neto, M.E., Ramiro,B.O., Santos, I.T.F., Guerra, R.R. (2018). Histomorphologic characterization of the hepatopancreas of freshwater prawn Macrobrachium rosenbergii (De Man, 1879). Arq. Bras. Med. Vet. Zootec, 70 (5):1539-1546

51.Singh, D. (1977). Yunani Dravyaguna part III, Ayurvedic and Tibii Academy, Lucknow. India.

52.Singh, S.R., Srivastav, V.K. and Kumar, Rajesh. (1988). Observation on the oocyte differentiation and vitellogenesis in the ganga water prawn, Macrobrachium birmanicum choprai (Tiwari). J.Adv.Zool. 9(1): 46-50

53.Sofia Miniadis-Meimaroglou and Vassilia J. Sinanoglou. (2012). Lipid profile and nutritional evaluation of shrimps. Transworld Research Network. 661 (2):21-40

54.Turan, T., Kaya, Y., Erdem, M.E. (2011). Proximate composition cholesterol and fatty acid content of brown shrimp (Crangon crangon L.1758) from Sinop Region, Black Sea. J Aquatic Food Prod Technol. 20:100-07

55.Varadarajan, S. and Subramoniam, T. (1982). Biochemical changes during vitellogenesis in a hermit crab Calbanarius calbanarius. Progress in Invertebrate Reproduction and Aquaculture (Eds). 7-14

56.Vazhiyil, Venugopal. and Kumarapanicker, Gopakumar. (2017). Shellfish: Nutritive Value, Health Benefits, and Consumer Safety. Comprehensive Reviews in Food Science and Food Safety. 16: 1219-1242

57.Victor, B. (1987). Reproductive and lipid cycles in the atyid prawn Caridina rajadhari (Bouvier). Indian J.Fish. 34 (3): 333-336

58.Victor, B. and Sarojini, R. (1985). Oocyte differentiation and vitellogenesis in the caridean prawn Caridina rajadhari (Bouvier). Current Sciences. 54(13): 647649

59.Webb, D. (2011) Freshwater shrimp (Palaemonetes australis) as a potential bioindicator of crustacean health. Environ Monit Assess (2011) 178: $537-544$ https://doi.org/10.1007/s10661-010-1711-1

60.Wolin, E.M., Lufer, H. and Albertini, D.F. (1973). Uptake of the yolk protein, lipovitellin by developing crustacean oocytes. Develop. Biol. 35: 160-162 